\title{
PENGARUH HARGA DAN KUALITAS PELAYANAN TERHADAP KEPUASAN PELANGGAN (STUDI KASUS PADA PT. GO-JEK)
}

\author{
Siti Solikha ${ }^{1}$, Imam Suprapta ${ }^{2}$ \\ STIE Muhammadiyah Jakarta ${ }^{1}$, sitisolikha29@gmail.com \\ STIE Muhammadiyah Jakarta², suprapta2017@gmail.com
}

\begin{abstract}
ABSTRAK
Kepuasan pelanggan pada PT. GO-JEK tidak menurun atau meningkat setiap tahunnya, ini dikarenakan startegi yang terus berusaha agar bisa selalu memuaskan para pelanggannya. Penelitian ini dilakukan untuk mengetahui bukti empris pengaruh harga dan kualitas pelayanan terhadap kepuasan pelanggan pada PT.GO-JEK diwilayah sekitar Tebet. Penentuan hasil sampel ini menggunakan rumus Lemeshow, dari rumus tersebut diperoleh sebanyak 74 responden dan diambil secara area (cluser) sampling (sampling menurut daerah). Teknik analisa data dalam penelitian dengan menggunakan analisis regresi berganda dengan program digunakan adalah SPSS versi 17.00. Hasil penelitian ini menunjukkan bahwa semua hipotesis dapat diterima, 1) terdapat pengaruh positif dan signifikan antara harga terhadap kepuasan pelanggan dapat diterima.2) terdapat pengaruh positif dan signifikan kualitas pelayanann terhadap kepuasan pelanggan dapat diterima. Harga merupakan variabel yang paling berpengaruh terhadap kepuasan pelanggan pengguna ojek online PT. GO-JEK.
\end{abstract}

Kata kunci: harga; kualitas pelayanan; kepuasan pelanggan

\section{ABSTRACT}

Customer satisfaction at PT. GO-JEK does not decrease or increase every year, this is due to strategies that continue to strive to always be able to satisfy their customers. This research was conducted to find empirical evidence of the effect of price and service quality on customer satisfaction at PT. GO-JEK in the area around Tebet. Determination of the results of this sample using the Lemeshow formula, from the formula obtained as many as 74 respondents and taken by area (cluser) sampling (sampling by region). Data analysis techniques in the study using multiple regression analysis with the program used was SPSS version 17.00. The results of this study indicate that all hypotheses can be accepted, 1) there is a positive and significant effect between price on customer satisfaction acceptable. 2) There is a positive and significant effect on service quality on customer satisfaction can be accepted. Price is the most influential variable on customer satisfaction of PT. GO-JEK.

Keywords: price; service quality; customer satisfaction

\section{PENDAHULUAN}

Dengan adanya pertumbuhan penduduk yang semakin meningkat mempengaruhi kebutuhan akan jasa transportasi yang semakin meningkat pula, hal ini lah yang menyebabkan semakin berkembangnya dunia bisnis di sektor jasa transportasi. Sejak dahulu, fenomena transportasi umum di Indonesia khususnya di daerah kota Jakarta begitu memprihatinkan. Mulai dari kondisi fisik kendaraan, hingga kondisi si pengemudi. Banyak angkutan yang sudah tidak layak pakai namun tetap di operasikan, berbagai tindak kriminal pun kerap kali terjadi. Tidak cukup dengan masalah yang terjadi pada kendaraan, masalah pada supirnya pun kerap kali 
muncul. Mulai dari supir tembak hingga supir yang belum memiliki SIM. Cara mereka membawa kendaraan jauh dari normalnya standar-standar dalam mengemudi. Kebut-kebutan, ugal-ugalan, hingga melanggar rambu-rambu lalu lintas. Padahal bagi masayarakat kelas ekonomi bawah yang tidak memiliki kendaraan pribadi, transportasi umum ini lah yang menjadi mobilitas sehari-hari masyarakat.

Bahasan ini sering kali menjadi polemik dan menjadi berita aktual yang tidak ada habisnya. Belum lama ini muncul sebuah terobosan baru dalam hal transportasi umum, yaitu ojek online yang bisa dipesan melalui smartphone / telepon genggam kita. Banyak kemudahan yang bisa di dapatkan, mulai dari tarif yang dihitung berdasarkan jarak kilometernya hingga pengguna yang dapat langsung diposisikan dengan ojek terdekat sehingga mempercepat waktu dalam menjemput pengguna.

GO-JEK merupakan salah satu penyedia layanan jasa transportasi online khususnya sepeda motor. GO-JEK adalah perusahaan berjiwa sosial yang memimpin revolusi industri transportasi Ojek. GO-JEK bermitra dengan para pengendara Ojek berpengalaman di Jakarta meliputi area JABODETABEK, Bandung, Bali \& Surabaya. Tidak hanya untuk antar-jemput, GO-JEK pun menyediakan berbagai layanan lain seperti GO-FOOD yang dapat menjemput makanan favorit anda darimana saja sesuai pesanan anda, kemudian ada GO-MART salah satu layanan GOJEK yang siap sedia untuk membelanjakan kebutuhan anda sehari-hari dan masih banyak lagi fitur-fitur yang diberikan oleh GO-JEK Indonesia. Walaupun GO-JEK sudah tidak asing lagi dikalangan masyarakat khususnya di kota Jakarta namun jasa di bidang transportasi ini harus tetap memperhatikan kenyamanan, keamanan serta kepuasan konsumennya. Jika konsumen puas akan pelayanan yang diberikan oleh GO-JEK maka pelanggan GO-JEK akan menggunakan jasa GO-JEK secara berulang (repeat buying) yang kemudian bisa menjadi pelanggan yang setia (loyal customer) sehingga perusahaan GO-JEK Indonesia sangat berpeluang menjadi market leader dan hal ini akan menjadikan perusahaan semakin maju dan dipercaya oleh pelanggan di Indonesia. Sebagai sebuah perusahaan jasa tentunya GO-JEK juga telah berupaya menerapkan strategi harga, dan kualitas pelayanan yang tepat guna menarik konsumen untuk menggunakan kembali jasa GO-JEK.

Faktor harga sangat mempengaruhi terhadap keputusan penggunaan jasa, GO-JEK sebagai perusahaan jasa menawarkan harga yang relatif terjangkau dibandingkan dengan perusahaan jasa yang lain, adanya potongan harga yang diberikan sehingga membuat konsumen tertarik untuk menggunakan jasa mereka. Harga adalah sejumlah uang yang dibebankan atas suatu produk atau jasa, atau jumlah dari nilai yang ditukar konsumen atas manfaat-manfaat karena memiliki atau menggunakan produk atau jasa tersebut (Kotler dan Armstrong, 2010: 314). Kunci lain untuk mempertahankan pelanggan adalah dengan memberikan kualitas pelayanan yang pada akhirnya akan menciptakan kepuasan pelanggan. Menurut Fandy Tjiptono (2014) Kualitas pelayanan adalah berfokus pada pelayanan kebutuhan dan keinginan konsumen serta ketepatan penyampainnya untuk mengimbangi harapan konsumen.

Penelitian sebelumnya dilakukan oleh Utari \& Mohamad Maskan (2019), yang menyatakan bahwa harga berpengaruh terhadap kepuasan pelanggan. Penelitian tentang kualitas pelayanan dilakukan oleh Deliyani \& Bono (2019) dan Sri \& Lela (2019) yang menyatakan bahwa kualitas layanan juga berpengaruh terhadap kepuasan pelanggan. Penelitian yang sama di lakukan oleh Nafisah (2016) menyatakan bahwa harga dan kualitas pelayanan berpengaruh positif dan signifikan terhadap kepuasan pelanggan. Peneitian berbeda dihasilkan oleh Tyas Kurniawati (2019), yang menyatakan bahwa harga tidak berpengaruh terhadap kepuasan konsumen.

Sebagai agen perubahan (Agent of Change), masyarakat tidak hanya menjadi penggagas perubahan, melainkan menjadi objek atau pelaku dari perubahan tersebut. Perubahan dari transportasi konvensional ke transportasi Online (dalam hal ini ojek Online) membuat GO-JEK 
menargetkan masyarakat sebagai targer utamanya. Dalam hal ini saya memilih masyarakat DKI Jakarta sebagai objek penelitian.

\section{KAJIAN LITERATUR Harga}

Menurut Basu Swastha (2010:147) harga merupakan sejumlah uang (ditambah beberapa barang kalau mungkin) yang dibutuhkan untuk menambahkan sejumlah kombinasi dari barang beserta pelayanannya. Menurut Siti Nurhalimah, dkk (2018) harga merupakan nilai (biasa dinyatakan dengan uang) yang harus di korbankan untuk dapat memiliki, menggunakan atau mengkonsumsi suatu barang dan jasa guna mendapatkan kepuasan. Jadi dapat disimpulkan jika harga sangat tinggi, konsumen biasanya mengharapkan kualitas tinggi, dan persepsi aktualnya akan dipengaruhi oleh harapan ini. Jika harga terlalu tinggi, organisasi dianggap tidak peduli akan pelanggan, atau dianggap melakukan penipuan. Sebaliknya, jika harga terlalu rendah, pelanggan dapat meragukan kemampuan organisasi dalam hal kualitas jasa.

Harga juga merupakan satu-satunya elemen bauran pemasaran yang menghasilkan pendapatan semua elemen lainnya hanya mewakili harga. Harga merupakan salah satu elemen yang paling fleksibel dari bauran pemasaran. Tidak seperti sifat-sifat produk dan komitmen jalur distribusi, harga dapat berubah dengan cepat. Menurut Mar'ari (2016) indikator harga adalah :

a. Keterjangkauan harga.

b. Kesesuaian harga dengan kualitas produk.

c. Daya saing harga.

d. Kesesuaian harga dengan manfaat.

\section{Kualitas Pelayanan}

Menurut Ratih (2010) service quality adalah seberapa jauh perbedaan antara harapan dan kenyataan para pelanggan atas layanan yang mereka terima. Service Quality dapat diketahui dengan cara membandingkan persepsi pelanggan atas layanan yang benar-benar mereka terima dengan layanan sesungguhnya yang mereka harapkan. Kualitas pelayanan menjadi hal utama yang diperhatikan serius oleh perusahaan, yang melibatkan seluruh sumber daya yang dimiliki perusahaan.

Sunarto (2003:244) mengidentifikasikan tujuh dimensi dasar dari kualitas yaitu:

a. Kinerja, yaitu tingkat absolut kinerja barang atau jasa pada atribut kunci yang diidentifikasi para pelanggan.

b. Interaksi pegawai, yaitu seperti keramahan, sikap hormat, dan empati ditunjukkan oleh masyarakat yang memberikan jasa atau barang.

c. Keandalan, yaitu konsistensi kinerja barang, jasa dan toko.

d. Daya tahan, yaitu rentan kehidupan produk dan kekuatan umum.

e. Ketepatan waktu dan kenyaman, yaitu seberapa cepat produk diserahkan atau diperbaiki, seberapa cepat produk infomasi atau jasa diberikan.

f. Estetika, yaitu lebih pada penampilan fisik barang atau toko dan daya tarik penyajian jasa.

g. Kesadaran akan merek, yaitu dampak positif atau negatif tambahan atas kualitas yang tampak, yang mengenal merek atau nama toko atas evaluasi pelanggan.

\section{Kepuasan Pelanggan}

Kepuasan pelanggan adalah pengukuran atau indikator sejauh mana pelanggan atau pengguna produk perusahaan atau jasa sangat senang dengan produk-produk atau jasa yang diterima. Kepuasan pelanggan merupakan perbandingan antara harapan terhadap presepsi pengalaman (dirasakan/diterima). Didin \& Anang ( 2019). 
Menurut M. Anang (2018) kepuasan pelanggan adalah pengukuran pelanggan atau pengguna produk perusahaan atau jasa sangat senang dengan produk-produk atau jasa yang diterima.

Sedangkan menurut Zulian Yamit (2005) dalam M. Anang (2018) Kepuasan konsumen merupakan evaluasi purna beli atau hasil evaluasi setelah membandingkan apa yang dirasakan dengan harapannya. Dalam konsep kepuasan konsumen, terdapat dua elemen yang mempengaruhi yaitu, harapan dan kinerja.

\section{Pengembangan Hipotesis}

Harga juga merupakan satu-satunya elemen bauran pemasaran yang menghasilkan pendapatan semua elemen lainnya hanya mewakili harga. Harga merupakan salah satu elemen yang paling fleksibel dari bauran pemasaran. Tidak seperti sifat-sifat produk dan komitmen jalur distribusi, harga dapat berubah dengan cepat. dan penjual melalui proses tawar-menawar, sehingga terjadilah kesepakatan harga tertentu.

Menurut Utari dan Mohamad Maskan (2019) pada penelitiannya yang berjudul "Pengaruh Harga dan Citra Perusahaan Terhadap Kepuasam Pelanggan J\&T Express Malang", menyatakan bahwa harga berpengaruh terhadap kepuasan pelanggan. Hal ini sejalan dengan penelitian yang dilakukan oleh Astri dkk (2016) bahwa harga memiliki pengaruh yang signifikan terhadap kepuasan pelanggan.

Berdasarkan teori dan penelitian terdahulu, maka hipotesis pertama penelitian ini adalah :

\section{H1 : Harga berpengaruh positif terhadap kepuasan pelanggan}

Menurut Ratih (2010) service quality adalah seberapa jauh perbedaan antara harapan dan kenyataan para pelanggan atas layanan yang mereka terima. Service Quality dapat diketahui dengan cara membandingkan persepsi pelanggan atas layanan yang benar-benar mereka terima dengan layanan sesungguhnya yang mereka harapkan. Kualiatas Pelayanan akan tergambar jika layanan melebihi harapan konsumen, maka konsumen akan merasa puas dengan pelayanan tersebut.

Menurut Deliyani \& Bono (2019) dan Sri \& Lela (2019) menyatakan bahwa kualitas pelayanan berpengaruh terhadap kepuasan pelanggan, hal ini sejalan dengan penelitian yang di lakukan oleh Rifaldi (2016) dan Ela \& Nova (2019) yang menjelaskan bahwa kualitas pelayanan berpengaruh positif dan signifikan terhadap kepuasan pelanggan. Sehingga hipotesis kedua penelitian ini adalah :

\section{H2 : Kualitas pelayanan berpengaruh positif terhadap kepuasan pelanggan}

Tjiptono (2008) menjelaskan bahwa harga merupakan salah satu variabel penting dalam pemasaran, dimana harga dapat mempengaruhi konsumen dalam mengambil keputusan. Selain harga, kualitas pelayanan juga mempengaruhi kepuasan pelanggan. Tjiptono (2002) mengungkapkan bahwa kualitas memiliki hubungan yang erat dengan kepuasan pelanggan. Perusahaan dengan tingkat kepuasan pelanggan yang tinggi maka tingkat layanan pelanggan yang disediakan akan tinggi pula. Kotler (2002) menjelaskan bahwa terdapat hubungan yang erat antara kualitas pelayanan, kepuasan pelanggan, dan profitabilitas perusahaan. Semakin tinggi tingkat kualitas pelayanan maka semakin tinggi jugakepuasan pelanggan dan hal ini dapat mendukung harga yang lebih tinggi serta biaya yang lebih rendah.

Peneliitian sebelumnya dilakukan oleh Nafisah (2016) yang membuktikan bahwa harga dan kualitas pelayanan berpengaruh positif dan signifikan terhadap kepuasan pelanggan. Penelitian lainnya dilakukan oleh Dewi, dkk (2018) yang menyatakan bahwa harga dan kualitas pelayanan berpengaruh terhadap kepuasan pelanggan. 
Berdasarkan teori dan penelitian tedahulu maka hipotesis ke tiga penelitian ini adalah :

\section{H3 : Harga dan kualitas pelayanan berpengaruh positif terhadap kepuasan pelanggan.}

\section{Kerangka Pemikiran}

Berdasarkan teori dan penelitian terdahulu maka kerangka pikirnya adalah sebagai berikut :

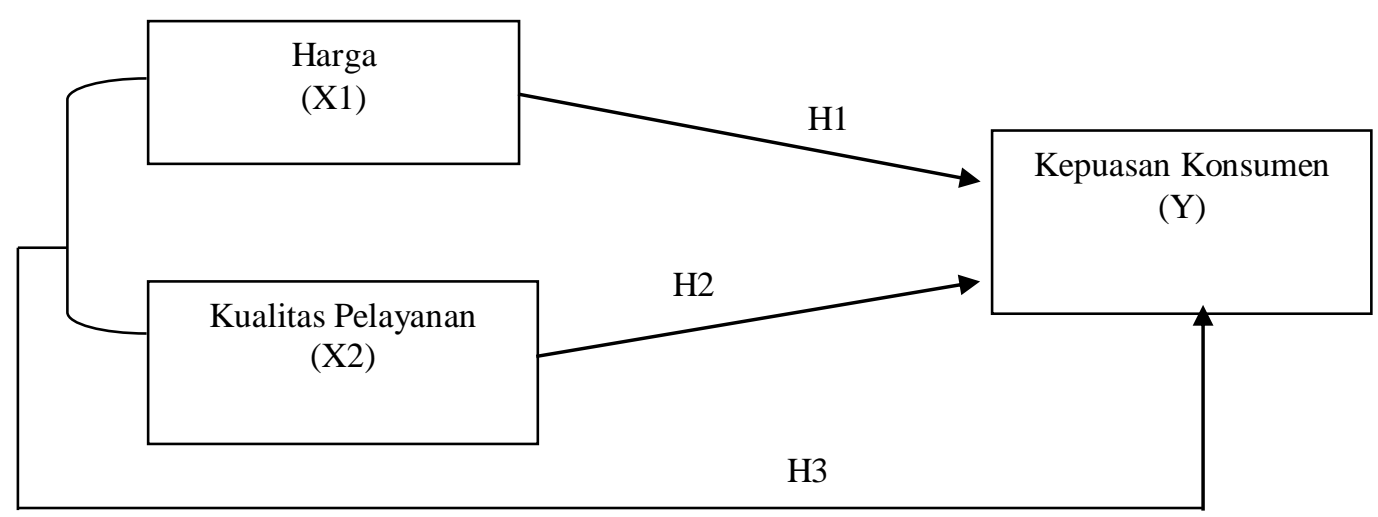

\section{Gambar 1. Kerangka Pemikiran}

\section{METODE PENELITIAN}

Penelitian ini dilakukan pada bulan Februari-Juli 2019 di PT. GO-JEK Jalan Iskandar II no. 7 RT 003/RW 001, Melawai, Kebayoran Baru, Kota Jakarta Selatan, Jakarta. Jenis data yang diperlukan dalam penelitian ini yaitu data primer yang di peroleh dengan melakukan pendekatan peneltian lapangan dengan kuisioner. Kuesioner berisi 15 pertanyaan, 5 pertanyaan mengenai harga, 5 pertanyaan mengenai kualitas pelayanan dan 5 pertanyaan mengenai kepuasan pelanggan. Teknik pengukuran skor menggunakan skala likert yaitu skala yang digunakan untuk mengukur sikap, pendapatan, dan persepsi seseorang.

Pada penelitian ini jumlah konsumen yang menggunakan jasa pelayanan GO-JEK tidak diketahui dengan pasti sehingga untuk menghitung jumlah sampel minimum yang dibutuhkan menggunakan formula Lemeshow untuk populasi yang tidak diketahui. Dari hasil perhitungan sampel ditentukan reponden dalam penelitian ini adalah 75 responden.

Variabel di dalam penelitian ini terdiri dari 2 variabel bebas (independent variable) dan satu variabel terikat (depedent variable). Variabel bebas tersebut adalah variabel harga (X1) dan variabel kualitas pelayanan (X2), serta variabel terikat kepuasan pelanggan (Y).

\section{Table 1.}

Definisi Operasional Variabel Harga, Kualitas Pelayanan dan Kepuasan Pelanggan

\begin{tabular}{|c|c|c|}
\hline Variabel & Konsep Variabel & Indikator \\
\hline $\begin{array}{l}\text { Harga }(\mathrm{X} 1) \\
(\text { variabel } \\
\text { independent })\end{array}$ & $\begin{array}{l}\text { satu-satunya elemen } \\
\text { bauran pemasaran } \\
\text { yang menghasilkan } \\
\text { pendapatan, elemen- } \\
\text { elemen lainnya } \\
\text { menimbulkan biaya }\end{array}$ & $\begin{array}{l}\text { 1. Keterjangkauan harga } \\
\text { 2. Kesesuaian harga } \\
\text { 3. Daya saing harga } \\
\text { 4. Harga berselisih } \\
\text { 5. Harga sesuai manfaat }\end{array}$ \\
\hline $\begin{array}{l}\text { Kualitas } \\
\text { Pelayanan (X2) }\end{array}$ & $\begin{array}{l}\text { tingkat keunggulan } \\
\text { yang diharapkan dan }\end{array}$ & $\begin{array}{l}\text { 1. Kenyamanan } \\
\text { 2. Fasilitas }\end{array}$ \\
\hline
\end{tabular}




\begin{tabular}{|c|c|c|}
\hline $\begin{array}{l}\text { (variabel } \\
\text { independent })\end{array}$ & $\begin{array}{l}\text { pengendalian atas } \\
\text { tingkat keunggulan } \\
\text { untuk memenuhi } \\
\text { keinginan konsumen }\end{array}$ & $\begin{array}{ll}\text { 3. } & \text { Ketepatan Waktu } \\
\text { 4. } & \text { Tanggapan pegawai } \\
\text { 5. } & \text { Penampilan }\end{array}$ \\
\hline $\begin{array}{l}\text { Kepuasan } \\
\text { Pelanggan (Y) } \\
\text { (variabel } \\
\text { dependent })\end{array}$ & $\begin{array}{l}\text { perasaan senang atau } \\
\text { kecewa seseorang } \\
\text { yang muncul setelah } \\
\text { membandingkan } \\
\text { kinerja (hasil) produk } \\
\text { yang dipikirkan } \\
\text { terhadap } \quad \text { kinerja } \\
\text { (hasil) } \\
\text { diharapkan }\end{array}$ & $\begin{array}{l}\text { 1. Persepsi kinerja } \\
\text { 2. Kesesuaian harapan } \\
\text { 3. Penilaian pelanggan } \\
\text { 4. Dapat memenuhi } \\
\text { kebutuhan } \\
\text { 5. Tanpa adanya salah } \\
\text { paham }\end{array}$ \\
\hline
\end{tabular}

\section{HASIL PENELITIAN DAN PEMBAHASAN}

\section{Karakteristik Responden}

Data menunjukan bahwa dari 75 responden, responden dengan jenis kelaminnya laki-laki berjumlah 40 orang $(55 \%)$ dan perempuan berjumlah 35 orang $(45 \%)$. Dengan 28 orang memiliki pekerjaan sebagai mahasiswa, 28 orang sebagai karyawan swasta, 2 orang sebagai PNS, 12 orang sebagai wiraswasta dan pekerjaan lain sebanyak 5 orang. Responden kategori usia $>20$ tahun sebanyak 55 orang, $>30$ tahun sebanyak 18 orang, dan $>40$ tahun sebanyak 2 orang.

\section{Analisa Data \\ Uji Validitas}

Uji validitas dapat dilakukan dengan menghitung korelasi antara skor masing-masing butir pertanyaan dengan total skor. Pengujian validitas tiap butir dengan butir dengan analisis item, yaitu mengkorelasi skor tiap butir (corrected item total correlation) yang penyelesainnya yang dilakukan dengan menggunakan software SPSS versi 17.00 dan dikonsultasikan dengan nilai $\mathrm{r}$ kritis ( $\mathrm{r}$ tabel). Kriteria pengujian validitas adalah sebagai berikut :

Valid $\quad=r$ hitung $>r$ tabel

Tidak Valid $=r$ hitung $>r$ tabel

Tabel 2.

Hasil Uji Validitas Instrumen Variabel X1

Inter-Item Correlation Matrix

\begin{tabular}{|c|c|c|c|c|c|}
\hline No. & Instrumen & R tabel & R hitung & Keterangan & Kesimpulan \\
\hline 1 & X1.1 & 0.2242 & 0.802 & R table>R hitung & Valid \\
2 & X1.2 & 0.2242 & 0.683 & R table>R hitung & Valid \\
3 & X1.3 & 0.2242 & 0.740 & R table>R hitung & Valid \\
4 & X1.4 & 0.2242 & 0.827 & R table>R hitung & Valid \\
5 & X1.5 & 0.2242 & 0.789 & R table>R hitung & Valid \\
\hline
\end{tabular}

$(\mathrm{r}$ tabel $=\mathrm{n}=75=0.2242)$ 
Berdasarkan uji validitas seluruh pertanyaan kuesioner variabel X1 (harga) di atas, terlihat bahwa semua pertanyaan adalah valid, karena memiliki nilai $r$ hitung $>r$ tabel. Dengan demikian, pertanyaan variabel X1 yang layak dijadikan analisis adalah 5 pertanyaan.

Tabel 3.

Hasil Uji Validitas Instrumen Variabel X2

Inter-Item Correlation Matrix

\begin{tabular}{|c|c|c|c|c|c|}
\hline No & Instrument & R tabel & R hitung & Keterangan & Kesimpulan \\
\hline 1 & X2.1 & 0.2242 & 0.876 & R tabel > R hitung & Valid \\
2 & X2.2 & 0.2242 & 0.864 & R tabel > R hitung & Valid \\
3 & X2.3 & 0.2242 & 0.743 & R tabel > R hitung & Valid \\
4 & X2.4 & 0.2242 & 0.794 & R tabel > R hitung & Valid \\
5 & X2.5 & 0.2242 & 0.738 & R tabel > R hitung & Valid \\
\hline
\end{tabular}

$(\mathrm{r}$ tabel $=\mathrm{n}=75=0.2242)$

Berdasarkan uji validitas seluruh pertanyaan kuesioner variabel X2 (Kualitas Pelayanan) di atas, terlihat bahwa semua pertanyaan adalah valid, karena memiliki nilai $R_{\text {hitung }}>R_{\text {tabel. }}$. Dengan demikian, pertanyaan variabel X2 yang layak dijadikan analisis adalah 5 pertanyaan.

Tabel 4.

Hasil uji validitas instrumen variabel $\mathrm{Y}$

Inter-Item Correlation Matrix

\begin{tabular}{|c|c|l|l|l|c|}
\hline No & Instrumen & R tabel & R hitung & Keterangan & Kesimpulan \\
\hline 1 & Y1.1 & 0.2242 & 0.786 & R hitung > R tabel & Valid \\
2 & Y1.2 & 0.2242 & 0.699 & R hitung > R tabel & Valid \\
3 & Y1.3 & 0.2242 & 0.737 & R hitung > R tabel & Valid \\
4 & Y1.4 & 0.2242 & 0.811 & R hitung > R tabel & Valid \\
5 & Y1.5 & 0.2242 & 0.626 & R hitung > R tabel & Valid \\
\hline
\end{tabular}

$(\mathrm{r}$ tabel $=\mathrm{n}=75=0.2242)$

Berdasarkan uji validitas seluruh pertanyaan kuesioner variabel $\mathrm{Y}$ (Kepuasan Pelanggan) di atas, terlihat bahwa semua pertanyaan adalah valid, karena memiliki nilai $\mathrm{R}_{\text {hitung }}>$ $\mathrm{R}_{\text {tabel. }}$. Dengan demikian, pertanyaan variabel $\mathrm{Y}$ yang layak dijadikan analisis adalah 5 pertanyaan (Hasil Uji Korelasi dengan software SPSS terlampir).

\section{Uji Reliabilitas}

Reliabilitas terfokus pada persoalan akurasi ukuran dan hasilnya. Artinya reabilitas menunjukan seberapa besar pengukuran kendali pada subjek yang sama. Pengajuan kendala alat ukur dalam alat penelitian menggunakan reabilitas motode alpha (a) yang digunkan adalah metode Cronbach, yaitu:

Keterangan :

$$
a=\frac{k x}{1+(k-1) y}
$$

$\mathrm{a}=$ koefisien reabilitas

$\mathrm{r}=$ koefisien rata-rata korelasi antara variabel 
$\mathrm{k}=$ jumlah variabel bebas dalam persamaan

Pengukuran reliabilitas dilakukan dengan menguji Statistic Cronbach Alpha. Suatu variabel dikatakan reliable apabila variabel tersebut memberikan nilai > 0,60 (Wati, 2018:108)

Tabel 5.

Uji Reliabilitas X1

Reliability Statistics

\begin{tabular}{|c|r|r|}
\hline $\begin{array}{c}\text { Cronbach's } \\
\text { Alpha }\end{array}$ & $\begin{array}{c}\text { Cronbach's } \\
\text { Alpha Based on } \\
\text { Standardized } \\
\text { Items }\end{array}$ & N of Items \\
\hline .798 & .893 & 6 \\
\hline
\end{tabular}

Sumber: hasil diolah SPSS ver 17.00

Berdasarkan tabel diatas maka X1 dinyatakan reliabel karena Cronbach's Alpha 0.798

Tabel 6.

Uji Reliabilitas X2

Reliability Statistics

\begin{tabular}{|c|c|c|}
\hline $\begin{array}{c}\text { Cronbach's } \\
\text { Alpha }\end{array}$ & $\begin{array}{c}\text { Cronbach's } \\
\text { Alpha Based on } \\
\text { Standardized } \\
\text { Items }\end{array}$ & N of Items \\
\hline .806 & .914 & 6 \\
\hline
\end{tabular}

Sumber: hasil diolah SPSS ver 17.00

Berdasarkan tabel diatas maka X2 dinyatakan reliabel karena Cronbach's Alpha 0.806

Tabel 7.

Uji Reliabilitas Y1

Reliability Statistics

\begin{tabular}{|r|r|r|}
\hline $\begin{array}{c}\text { Cronbach's } \\
\text { Alpha }\end{array}$ & $\begin{array}{c}\text { Cronbach's } \\
\text { Alpha Based on } \\
\text { Standardized } \\
\text { Items }\end{array}$ & N of Items \\
\hline .787 & .869 & 6 \\
\hline
\end{tabular}

Sumber: hasil diolah SPSS ver 17.00

Berdasarkan tabel diatas maka Y1 dinyatakan reliabel karena Cronbach's Alpha 0.787

Berdasarkan pada hasil uji Reliabilitas X1,X2, dan Y1 maka dapat disimpulkan bahwa untuk variabel harga, kualitas pelayanan dan kepuasan pelaggan pembelian memiliki Cronbach's Alpha diatas 0,7 sehingga indikator-indikator yang telah digunakan pada variabel tersebut mempunyai reliabilitas yang baik.

\section{Analisa Koefiensi Korelasi}

Korelasi berarti hubungan begitu pula dengan analisis korelasi yaitu suatu analisis yang digunakan untuk melihat hubungan dua variabel. Perhitungan korelasi bertujuan untuk mengetahui berapa jumlah keofiensi dari variabel berikat dapat diterangkan oleh variabel bebas, serta untk mengetahui tingkat hubungan yang ada antara variabel $\mathrm{X} 1, \mathrm{X} 2$ dan $\mathrm{Y} 1$ untuk 
mengetahui hubungan antara X1, X2, dan Y1 dengan rumusan korelasi product moment sebagai berikut:

$$
r=\frac{\mathrm{n} \cdot \mathrm{XiYi}-(\mathrm{Xi})(\mathrm{Yi})}{\left\{\mathrm{n} \cdot \mathrm{Xi}^{2}-(\mathrm{Xi})^{2}\right\} \cdot\left\{\mathrm{n} \cdot \mathrm{Yi}^{2}-\left(\mathrm{Yi}^{\mathrm{i}}\right)^{2}\right\}}
$$

Dari hasil pengelolaan data dengan bantuan software SPSS versi 17.00

Tabel 8.

Analisis Korelasi X1

\begin{tabular}{|l|l|c|c|}
\hline Model & $\mathrm{N}$ & $\mathrm{R}$ & R Square \\
\hline Harga & 74 & 0.521 & 0.272 \\
\hline \multicolumn{4}{|c|}{ Sumber: Hasil diolah SPSS ver 17.00} \\
\hline
\end{tabular}

Dari hasil perhitungan diatas $r=0.521$. hal ini menunjukan bahwa terdapat korelasi atau hubungan yang positif dan sangat kuat antara harga dengan keputusan pembelian. Hubungan positif dan sangat kuat artinya jika variabel harga (X1) mengalami kenaikan maka akan diikuti dengan peningkatan pada variabel kepuasan pelanggan (Y1) . begitu sebaliknya jika terdapatkan penurunan pada variabel harga (X1) maka akan diikuti dengan penurunan pada kepuasan pelanggan (Y1).

Tabel 9.

Analisis Korelasi X2

\begin{tabular}{|c|c|c|c|}
\hline Model & $\mathrm{N}$ & $\mathrm{R}$ & R Square \\
\hline Kualitas Pelayanan & 74 & 0.738 & 0.544 \\
\hline
\end{tabular}

Sumber: Hasil diolah SPSS ver 17.00

Dari hasil perhitungan diatas $r=0.738$. hal ini menunjukan bahwa terdapat korelasi atau hubungan yang positif dan sangat kuat antara harga dengan keputusan pembelian. Hubungan positif dan sangat kuat artinya jika variabel kualitas pelayanan (X2) mengalami kenaikan maka akan diikuti dengan peningkatan pada variabel kepuasan pelanggan (Y1) . begitu sebaliknya jika terdapatkan penurunan pada variabel kualitas pelayanan (X2) maka akan diikuti dengan penurunan pada kepuasan pelanggan (Y1).

Tabel 10.

Model Summary ${ }^{\text {b }}$

\begin{tabular}{|c|l|r|r|r|r|}
\hline Model & R & R Square & Adjusted R Square & Std. Error of the Estimate & Durbin-Watson \\
\hline 1 & $.753^{\mathrm{a}}$ & .567 & .554 & 2.05367 & 2.019 \\
& & & & & \\
\hline
\end{tabular}

a. Predictors: (Constant), X2, X1

b. Dependent Variable: Y1

Dari hasil perhitungan diatas $r=0.753$. hal ini menunjukan bahwa terdapat korelasi atau hubungan yang positif dan sangat kuat antara harga dengan keputusan pembelian. Hubungan positif dan sangat kuat artinya jika variabel harga (X1) dan kualitas pelayanan (X2) mengalami kenaikan maka akan diikuti dengan peningkatan pada variabel kepuasan pelanggan (Y1) . 


\section{Analisis Determinasi}

Setelah diperoleh nilai $\mathrm{r}$ maka dicari nilai Koefiensien Determinasi (KD) dengan mengkuadratkan hasil $\mathrm{r}$ kemudian dikalikan dengan setarus persen.

$$
\begin{aligned}
& \text { Analisa Determinasi X1 } \\
& \begin{aligned}
\mathrm{KD} & =\mathrm{r}^{2} \times 100 \% \\
& =(0.521)^{2} \times 100 \% \\
& =27,1 \%
\end{aligned}
\end{aligned}
$$

Koefisien determinasi digunakan untuk mengetahui berapa persen pengaruh variabel bebas terhadap variabel terikat. Dalam hasil ini besarannya persentase hubungan antara variabel $\mathrm{X} 1$ dan Y1. Diperoleh nilai R Square (KD) sebesar 0,271. Dengan demikian variabel harga (X1) mampu menerangkan variabel kepuasan pelanggan (Y1) sebesar $27,1 \%$ sedangkan sisanya sebesar 72.9\% dipengaruhi oleh variabel lain diluar penelitian.

$$
\begin{aligned}
& \text { Analisa Determinasi X2 } \\
& \begin{aligned}
\mathrm{KD} & =\mathrm{r}^{2} \times 100 \% \\
& =(0.738)^{2} \times 100 \% \\
& =54,4 \%
\end{aligned}
\end{aligned}
$$

Koefisien determinasi digunakan untuk mengetahui berapa persen pengaruh variabel bebas terhadap variabel terikat. Dalam hasil ini besarannya persentase hubungan antara variabel $\mathrm{X} 2$ dan Y1. Diperoleh nilai R Square (KD) sebesar 0,544. Dengan demikian variabel harga (X1) mampu menerangkan variabel kepuasan pelanggan (Y1) sebesar $54,4 \%$ sedangkan sisanya sebesar 45,6\% dipengaruhi oleh variabel lain diluar penelitian.

\section{Determinasi X1 dan X2}

Tabel 11.

Model Summary ${ }^{\mathrm{b}}$

\begin{tabular}{|c|c|r|r|r|r|}
\hline Model & $\mathrm{R}$ & $\begin{array}{c}\mathrm{R} \\
\text { Square }\end{array}$ & $\begin{array}{c}\text { Adjusted R } \\
\text { Square }\end{array}$ & $\begin{array}{c}\text { Std. Error of the } \\
\text { Estimate }\end{array}$ & $\begin{array}{c}\text { Durbin- } \\
\text { Watson }\end{array}$ \\
\hline 1 & $.753^{\mathrm{a}}$ & .567 & .554 & 2.05367 & 2.019 \\
\hline
\end{tabular}

a. Predictors: (Constant), X2, X1

b. Dependent Variable: Y1

Berdasarkan dari hasil analisa determinasi $\left(\mathrm{r}^{2}\right)$ tabel di atas, ialah variabel harga (X1) dan kualitas pelayanan (X2) jika digabung atau dihitung bersamaan maka hasilnya berbeda dengan hasil perhitungan masing-masing variabel sebelumnya.

\section{Analisa koefiensi Regresi}

Analisis regresi merupakan model analisis yang bertujuan mencari besarnya pengaruh antara variabel bebas $(\mathrm{X})$ terhadap variabel terikat $(\mathrm{Y})$. Persamaan regresi tersebut dapat dirumuskan:

$$
\begin{gathered}
\mathrm{Y}=\mathrm{a}+\beta 1 \mathrm{X} 1+\beta 2 \mathrm{X} 2 \\
\mathrm{Y}=2.720+0.187 \mathrm{X} 1+0.651 \mathrm{X} 2
\end{gathered}
$$

Berdasarkan hasil olah data diatas dapat dibuat persamaan garis regresinya 
$\mathrm{Y}=2,720+0,187 \mathrm{X} 2+0,651 \mathrm{X} 2$

Tabel 12.

Coefficients $^{\mathrm{a}}$

\begin{tabular}{|c|c|c|c|c|c|}
\hline \multirow[t]{2}{*}{ Model } & \multicolumn{2}{|c|}{$\begin{array}{l}\text { Unstandardized } \\
\text { Coefficients }\end{array}$} & \multirow{2}{*}{$\begin{array}{c}\text { Standardized } \\
\text { Coefficients } \\
\text { Beta }\end{array}$} & \multirow[b]{2}{*}{$\mathrm{t}$} & \multirow[b]{2}{*}{ Sig. } \\
\hline & $\mathrm{B}$ & Std. Error & & & \\
\hline $1 \quad$ (Constant) & 2.720 & 1.705 & & 1.595 & 115 \\
\hline $\mathrm{X} 1$ & 187 & .097 & .178 & 1.922 & .059 \\
\hline $\mathrm{X} 2$ & .651 & .094 & 643 & 6.950 & .000 \\
\hline
\end{tabular}

a. Dependent Variable: Y1

Konstanta (a) sebesar 2,720 menyatakan bahwa jika tidak ada variabel bebas (harga dan kualitas pelayanan ) atau variabel bebas bernilai nol, maka kepuasan pelanggan akan tetap (konstan) sebesar 2,720. Sedangkan koefisien regresi X1 sebesar 0,187 dan X2 sebesar 0,651 memiliki pengertian bahwa jika variabel bebas (Kepuasan Pelanggan ) meningkat satu kali akan meningkatkan kinerja karyawan sebesar 27,20\%.

\section{Uji T}

Uji T pada dasarnya menunjukan seberapa besar pengaruh sautu variabel bebas terhadap variabel terikat. Uji t digunakan untuk mengetahui signifikasi pengaruh harga (X1) dan kualitas pelayanan (X2) terhadap kepuasan pelanggan (Y1). Uji T dilakukan dengan menggunakan rumus sebagai berikut:

$$
t=\frac{r n-2}{1-r}
$$

Selanjutnya dengan nilai $\mathrm{t}$ hitung diperoleh tersebut dibandingkan dengan nilai $\mathrm{t}$ tabel. Berdasarkan hasil perhitungan dengan software SPSSv.17.00 diperoleh hasil sebagai berikut:

Tabel 13.

Hasil Uji t Harga (X1)

Coefficients $^{\mathrm{a}}$

\begin{tabular}{|c|c|c|c|c|c|}
\hline \multirow[t]{2}{*}{ Model } & \multicolumn{2}{|c|}{$\begin{array}{l}\text { Unstandardized } \\
\text { Coefficients }\end{array}$} & \multirow{2}{*}{$\begin{array}{c}\begin{array}{c}\text { Standardize } \\
\mathrm{d} \\
\text { Coefficients }\end{array} \\
\text { Beta }\end{array}$} & \multirow[b]{2}{*}{$\mathrm{t}$} & \multirow[b]{2}{*}{ Sig. } \\
\hline & $\mathrm{B}$ & Std. Error & & & \\
\hline $1 \quad$ (Constant) & 7.855 & 1.978 & & 3.971 & .000 \\
\hline X1 & .548 & . 106 & .521 & 5.184 & .000 \\
\hline
\end{tabular}

a. Dependent Variable: Y1

Sumber : Hasil diolah SPSS versi 17.00

Tabel 14.

Hasil Uji t Kualitas Pelayanan (X2)

\section{Coefficients $^{\mathbf{a}}$}




\begin{tabular}{|c|c|c|c|c|c|}
\hline \multirow[t]{2}{*}{ Model } & \multicolumn{2}{|c|}{$\begin{array}{l}\text { Unstandardized } \\
\text { Coefficients }\end{array}$} & \multirow{2}{*}{$\begin{array}{c}\text { Standardized } \\
\text { Coefficients } \\
\text { Beta }\end{array}$} & \multirow[b]{2}{*}{$\mathrm{t}$} & \multirow[b]{2}{*}{ Sig. } \\
\hline & B & $\begin{array}{l}\text { Std. } \\
\text { Error }\end{array}$ & & & \\
\hline $1 \quad$ (Constant) & 4.426 & 1.483 & & 2.984 & .004 \\
\hline $\mathrm{X} 2$ & .747 & .081 & .738 & 9.270 & .000 \\
\hline
\end{tabular}

a. Dependent Variable: Y1

Sumber : Hasil diolah SPSS versi 17.00

Hasil Uji t Harga (X1) dan Kualitas Pelayanan (X2)

Tabel 15.

Coefficients $^{\mathrm{a}}$

\begin{tabular}{|c|c|c|c|c|c|}
\hline \multirow[t]{2}{*}{ Model } & \multicolumn{2}{|c|}{$\begin{array}{c}\text { Unstandardized } \\
\text { Coefficients }\end{array}$} & \multirow{2}{*}{$\begin{array}{c}\begin{array}{c}\text { Standardized } \\
\text { Coefficients }\end{array} \\
\text { Beta }\end{array}$} & \multirow[b]{2}{*}{$\mathrm{t}$} & \multirow[b]{2}{*}{ Sig. } \\
\hline & B & $\begin{array}{l}\text { Std. } \\
\text { Error }\end{array}$ & & & \\
\hline (Constant) & 2.720 & 1.705 & & 1.595 & .115 \\
\hline $\mathrm{X} 1$ & .187 & .097 & .178 & 1.922 & .059 \\
\hline $\mathrm{X} 2$ & .651 & .094 & .643 & 6.950 & .000 \\
\hline
\end{tabular}

a. Dependent Variable: Y1

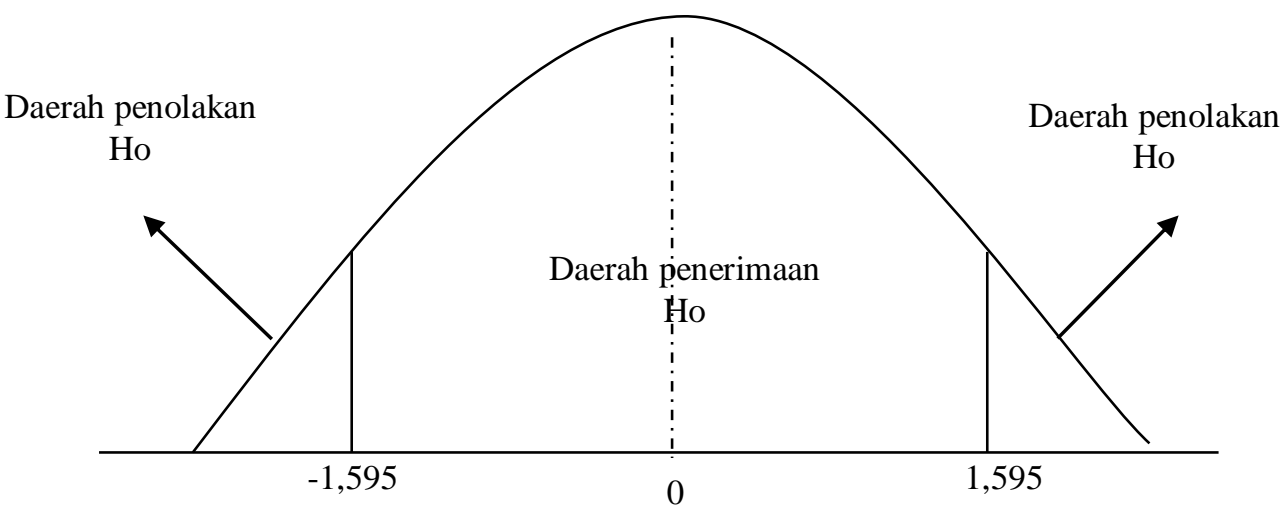

Gambar 2.

Berdasarkan hasil uji diatas bahwa $t$ tabel sebesar 1,595 $>t$ hitung 5,184 harga (X1) sedangkan 9,270 untuk variabel kualitas pelayanan (X2) maka dinyatakan diterima antara 2 variabel yaitu, harga (X1) dan kualitas pelayanan (X2) terhadap kepuasan pelanggan (Y1) tersebut.

\section{Uji F}

Untuk mengetahui pengaruh secara silmutan antara harga dan kualitas pelayanan terhadap kepuasan pelanggan maka dilakukan uji silmutan dengan membandingkan nilai $\mathrm{F}$ hitung dengan $\mathrm{F}_{\text {tabel }}$ ataupun dengan melihat angka signifikasinya (probabilitas). Rumusan hipotesis dikemukakan oleh Sari, $(2015 ; 51)$ sebagai berikut : 
Ho : h secara bersama-sama (simultan) antara harga (X1) dan kualitas pelayanan (X2) terhadap kepuasan pelanggan (Y1)

Ha : secara bersama-sama (simultan) antara harga (X1) dan kualitas pelayanan (X2) terhadap kepuasan pelanggan (Y1)

Ho ditolak dan Ha diterima jika $\mathrm{f}_{\text {hitung }}>\mathrm{f}_{\text {tabel }}$ artinya ada pengaruh secara bersama-sama antara harga (X1) dan kualitas pelayanan (X2) terhadap kepuasan pelanggan (Y1)

Tabel 16.

Uji Simultan (Uji f)

\begin{tabular}{|rc|r|r|r|r|r|}
\hline \multicolumn{1}{|c|}{ Model } & \multicolumn{1}{c|}{$\begin{array}{c}\text { Sum of } \\
\text { Squares }\end{array}$} & \multicolumn{1}{c|}{ Df } & \multicolumn{1}{c|}{$\begin{array}{c}\text { Sean } \\
\text { Square }\end{array}$} & F & Sig. \\
\hline 1 & Regression & 391.539 & 2 & 195.770 & 46.418 & $.000^{\mathrm{a}}$ \\
& Residual & 299.447 & 71 & 4.218 & & \\
& Total & 690.986 & 73 & & & \\
\hline
\end{tabular}

Sumber: Hasil diolah SPSS ver 17.00

$\mathrm{F}_{\text {hitung }}$ yang diperoleh pada output diatas sebesar 46.418 dan pada $t$ tabel nya sebesar 1.595 maka $46.418>1.595$ artinya hipotesis diterima dengan nilai probabilitias 0,000 jauh lebih kecil dari 0,005 maka model analisis regresi adalah signifikan sehingga diambil hipotesis bahwa Ho ditolak dan Ha diterima jika $\mathrm{f}_{\text {hitung }}>\mathrm{f}_{\text {tabel }}$ artinya ada pengaruh secara bersama-sama antara harga (X1) dan kualitas pelayanan (X2) terhadap kepuasan pelanggan (Y1)

\section{PEMBAHASAN}

\section{Pengaruh harga terhadap kepuasan pelanggan}

Berdasarkan hasil penelitian didapatkan hasil bahwa terdapat pengaruh positif dan signifikan antara harga terhadap kepuasan pelanggan. Hasil ini sesuai dengan penelitian yang dilakukan oleh Utari \& Mohamad Maskan (2019) dan Astri dkk (2016) bahwa harga memiliki pengaruh yang signifikan terhadap kepuasan pelanggan.

\section{Pengaruh kualitas pelayanan terhadap kepuasan pelanggan}

Hasil ini juga menunjukkan kualitas pelayanan berpengaruh positif dan signifikan terhadap kepuasan pelanggan. Hasil ini sejalan dengan yang dilakukan oleh Deliyani \& Bono (2019), Sri \& Lela (2019) dan Rifaldi (2016) yang menjelaskan bahwa kualitas pelayanan berpengaruh positif dan signifikan terhadap kepuasan pelanggan. Dengan demikian, kualitas pelayanan yang diberikan PT. GO-JEK sangat berpengaruh dengan kepuasan pelanggan.

\section{Pengaruh harga dan kualitas pelayanan terhadap kepuasan pelanggan}

Berdasarkan hasil penelitian yang dilakukan bahwa terdapat pengaruh positif dan signifikan antara harga dan kualitas pelayanan. Semakin baik harga dan kualitas pelayanan, maka semakin baik pula kepuasan pelanggan. Hal ini sesuai dengan hasil penelitian yang telah dilakukan sebelumnya oleh Nafisah (2016) dan Dewi, dkk (2018) yang membuktikan bahwa harga dan kualitas pelayanan berpengaruh positif dan signifikan terhadap kepuasan pelanggan. 
Hasil uji hipotesis antara harga dan kualitas pelayanan terhadap kepuasan pelanggan sebesar 5,184 dengan nilai t tabel 0,2242 >1,66 pada taraf signifikansi $\alpha=0,05(5 \%)$ yang menyatakan bahwa terdapat pengaruh positif dan signifikan antara harga > kepuasan pelanggan. Dengan demikan, hipotesis $\mathrm{H} 1$ pada penelitian ini, yaitu terdapat pengaruh positif dan signifikan harga terhadap kepuasan pelanggan dapat diterima. $\mathrm{H} 2$ pada penelitian ini, yaitu terdapat pengaruh positif dan signifikan kualitas pelayanann terhadap kepuasan pelanggan dapat diterima.

\section{PENUTUP}

Berdasarkan hasil pengolahan data dan pembahasan terhadap hasil penelitian yang dilakukan dengan analisis regresi berganda. Maka dapat disimpulkan bahwa ada pengaruh positif dan signifikan pada variabel harga terhadap kepuasan pelanggan jasa transportasi ojek online GOJEK, hasil ini berdasarkan penelitian yang menyatakan bahwa terdapat pengaruh positif dan signifikan antara harga dengan kepuasan pelanggan. Dengan demikan, hipotesis H1 pada penelitian ini, yaitu terdapat pengaruh positif dan signifikan harga terhadap kepuasan pelanggan dapat diterima. Variabel kualitas pelayanan berpengaruh positif dan signifikan terhadap kepuasan pelanggan jasa trnasportasi ojek online GOJEK, hasil ini berdasarkan hipotesis, yaitu terdapat pengaruh positif dan signifikan kualitas pelayanann terhadap kepuasan pelanggan dapat diterima.

Hasil penelitian ini, hanya terbatas dalam variabel harga dan kualitas pelayanan terhadap kepuasan pelanggan pada PT GO-JEK. Banyak beberapa faktor yang tidak mendukung dalam penelitian ini, seperi tidak dilengakapi dengan gambar grafik yang cukup jelas dalam mengolah data dan responden yang tidak terlalu banyak. Semoga untuk penelitian selanjutnya dapat melengkapi kurangan dalam penelitian ini, seperti citra merk, promosi dan masih banyak lainnya.

Bagi PT GO-JEK semoga hasil penelitian ini, dapat meningkatkan kepuasan pelanggan yang menggunakan layanan jasa PT GO-JEK di wilayah sekitar Tebet. Memperhatikan strategi penerapan harga dengan cara memberikan voucher, diskon atau promosi pada pelanggan setia. Selanjutnya, meningkatkan kualitas pelayanan dengan cara memberikan fasilitas dan keramahtamahan kepada setiap pelanggan GO-JEK.

\section{REFERENSI}

Astri, Desta, Meitry dan Niky (2016) Analisis Kepuasan Konsumen GOJEK Di Wilayah Kota Bandung

Deliyani, E. \& Prambudi, B. (2019). Pengaruh Kualitas Pelayanan Terhadap Kepuasan Pelayanan Pada Penumpang MRT. Jurnal Ekobis. Vol 9. No 2

Fitriadi. E. \& Rini. N. (2019). Pengaruh Kualitas Pelayanan Terhadap Kepuasan Konsumen Pada Showroom Perintis Motor. E-Journal Ekobis: Ekonomi Bisnis \& Manajemen. Vol. 9 No. 1

Fatihudin. D. \& Firmansyah. A. (2019). Pemasaran Jasa (Strategi, Mengukur Kepuasan dan Loyalitas Pelanggan). Deepublish:Yogyakarta

Firmansyah. M. A. (2018). Perilaku konsumen (sikap dan Pemasaran). Deepublish:Yogyakarta

Kurniawati, T., Irawan, B., \& Prasodjo, A. (2019). Analisis Pengaruh Kualitas Pelayanan, Harga, dan Brand Image Terhadap Kepuasan Konsumen Restoran Pizza Hut Cabang Jember. e-Journal Ekonomi Bisnis dan Akuntansi, 6(2), 147-151.

Kotler, Philip. 2002. Manajemen Pemasaran Edisi Millenium. Jakarta: PT.Prehallindo.

Kotler, Philip dan Gary Armstrong. 2010. Principles of Marketing (Edisi 13). United States of America: Pearson.

Nafisa Choirul Mar'ari (2016) Pengaruh Kualitas Pelayanan Dan Harga Terhadap Kepuasan 
Pelanggan Jasa Transportasi Ojek Online Gojek Di Surabaya

Nurhalimah, S., Hasiholan, L. B., \& Harini, C. (2018). Analisis Pengaruh Kualitas Pelayanan, Harga Dan Lokasi Terhadap Kepuasan Pelanggan (Studi Pada Bengkel Garasi Di Ungaran). Journal of Management, 4(4).

Pane. D. N,. El FIkri. M. \& Ritonga. M. (2018). Pengaruh Harga dan Kualitas Pelayanan Terhadap Kepuasan Pelanggan Pada Rumah Makan Sidempuan Medan. JUMANT, 9(1), $1-11$.

Pratiwi, U \& Maskan, M. (2019). Pengaruh Harga dan Citra Perusahaan terhadap Kepuasan Pelanggan J\&T Express Malang. JAB Jurnal Aplikasi Bisnis Volume:5 Nomor:1

Rahayu, S. \& Wati, L. N. (2018). Pengaruh Kualitas Pelayanan Terhadap Kepuasan Prlanggan dan Dampaknya Terhadap Loyalitas Pelanggan. E-Journal Ekobis: Ekonomi Bisnis \& Manajemen. Vol. 8 No. 2

Rifaldi dan Sulistyowati (2016) Pengaruh Kualitas Pelayanan Trasnportasi Online GOJEK Terhadap Kepuasan Pelanggan Pada Mahasiswa/I Administrasi Niaga Polteknik Negeri Jakarta

Swasta , Basu dan Irawan, 2010 . "Manajemen Pemasaran Modern”, Liberti , Yogyakarta Tjiptono, Fandy. 2002. Manajemen Jasa.Yogyakarta: Penerbit Andi.

Tjiptono, Fandy dkk. 2008. Pemasaran Strategik. Yogyakarta: Andi Offset.

Tjiptono, F. (2014). Pemasaran Jasa. Andi. Yogyakarta.

Hardiyati. R. (2010). Analisis Pengaruh Kualitas Pelayanan Tehadap Kepuasan Konsumen Menggunakan Jasa Penginapan (Villa) Agrowisata Kebun The Pagilaran. Skripsi. Fakultas Ekonomi Universitas Diponegoro: Semarang

Sunarto. 2003. Perilaku Konsumen. Yogyakarta : AMUS Jogyakarta dan CV Ngeksigondo Utama.

Wati L.N. (2018) Metodologi Penelitian Bisnis Terapan, Aplikasi SPSS, EVIEWS, Smart PLS dan AMOR: Bekasi 